\title{
Finding My Place: Home and Identity in Brooklyn Film
}

\author{
A Tusita \\ Malang, Indonesia \\ \{arcci_tusita@ub.ac.id\}
}

\begin{abstract}
This study discusses the journey experienced by Eilis, the main character in the film Brooklyn, in defining her identity. As Irish young women who emigrates to United Stated in 1950s, Eilis is caught between two worlds which create conflicts in herself. This qualitative descriptive study uses Stuart Hall's identities theory to examine the way Eilis finds the place that she can call home which eventually leads her to define her position and identity. The findings show that Eilis' internal conflicts are caused by her efforts to find sense of belongingness: a home, both in foreign and home land. Through this personal journey in finding home, Eilis is able to define her positions individually and culturally in multicultural world that finally influence her attitude toward differences.
\end{abstract}

Keywords: Finding My Place, Identity, Brooklyn.

\section{INTRODUCTION}

Our modern day societies are becoming increasingly intercultural, with people from different cultural backgrounds coming together and being expected to co-exist with each other despite sometimes having very different values, traditions and norms. Due to the increasing of diversity in society, finding one's own identity has become harder than ever. Phenomena like migrations, modernization and globalization change people's perception of their surroundings and other cultures, as well as their sense of cultural self-awareness. Thus, the world is becoming a global playing field and different cultures are coming increasingly closer resulting in the Self/Other dynamic which causes questions about sense of belonging. This is in line with Etoroma's (2006: 107) argument that "one of the most enduring legacies of modernity is the homelessness - the sense of alienation and identity crisis - it creates." The problem of the life of immigrants and their problems related to the issue of identity and sense of belongingness is the theme that occasionally raised in multicultural works, especially film as representation media, one of which is Brooklyn.

Eilis Lacey, the protagonist of the film Brooklyn experienced 'exile' throughout her life which trigger her quest in finding a place she can call home. Growing up in small city of Enniscorthy in Ireland, she decides to emigrate to America since she feels the lack of career opportunity in her homeland. The film also depicts how the border crossing undergoes by Eilis becomes identity crossing. Although Brooklyn is indeed the land of opportunity where she gets decent job in prestigious shop, she is continuously feels alienated in this strange country far away from home. She is trapped in the feeling of melancholia and homesickness. It is her sister sudden and tragic death and duty as daughter to accompany her now alone widowed mother that 
calls Eilis back home to Enniscorthy. It is when Eilis realizes how much she changes and living in small community like her homeland make her feel exiled in different way.

Identity is individual's sense of self derived from formal or informal membership in groups that transmit and inculcate knowledge, beliefs, values, attitudes, traditions, and ways of life. Identity is vitally needed by human beings to identify themselves with their surroundings and to make sense of their existence. As Woodward's (1997:1) statement that "Identity gives us a location in the world and presents the link between us and society in which we live...identity gives us an idea of who we are and how we relate to others and to the world in which we live". In fact, identity changes over time and many times create crisis or conflict. It is intertwined with power and privilege, affected by close relationships, and negotiated through communication. Thus, identity formation is not static, but a process which is always in motion and is never complete. People and their surroundings are constantly changing and since humans are shaped by their surroundings, their identity is always changing as well. As Hall's (1997: 4) statement below.

Identities are never unified and, in late modern times, increasingly fragmented and

fractured; never singular but multiply constructed across different, often intersecting

and antagonistic, discourses, practices and positions. They are subject to a radical

historicization, and are constantly in the process of change and transformation.

The long quest in defining and redefining self and also finding a place in this big multicultural world is clearly depicted in Brooklyn movie. The protagonist Eilis Lacey embodies the difficulty of the exile and the inner self of lonely immigrant as she tries to make sense of her new existence in unfamiliar place. Therefore, this paper focuses in discussing two aspects depicted in the film. First, Eilis's conflicts caused by her constantly exiled feeling both in home and new land. Second, Eilis' journey to find sense of belonging as the effort to overcome the conflict.

\subsection{Reserch Method}

Broadly speaking, identity is a concept about self. It can be defined as a state of being whom or what a person is, and his/her distinctiveness that distinguish him/her from others. The traditional concept of identity is inseparably tagged to rigid and hierarchical social structure and system of values. Such a notion inevitably points to the essentialist concept of identity that emphasizes 'essence' as the 'core' attributed to a person on the basis of his birth, dignity and status in society. On the other words, the essentialist notion of identity is 'fixed' and 'constant' throughout an individual life and that it is something 'given' by birth.

This essentialist notion of identity has been strongly contested by many critics. MacIntyre (1981: 5) argues that modern society is not built upon the notion of harmony and that in the midst of confusion, moral laxity and spiritual sterility, a modern man could hardly nourish a coherent set of values for securing a satisfactory identity. Thus, a modern man lives through fragmentary existence and experiences a split personality, conflicting condition and advanced social situation that demand new forms of identity rather than the fixed one. Moreover, Stuart Hall (1997) argues that identity is the product of several factors such as power, politics, patriarchy, racial and gender discrimination and bondage of cultural hegemony following globalization, migration, commercial transaction and cultural interaction among people in multilingual and multi-cultural contexts. The question of identity is highly associated with transformation and therefore it always encourages dynamism.

As the opposite of essentialist, non-essentialist believes that identity is never fixed or static. In the globalized world with increasing intercultural encounters, identity is constantly enacted, 
negotiated, maintained, and challenged through communicative practices. Thus, it can be said that identity is not a constant essence. Identity becomes a problem when crisis happens, that is when something regarded as the "essence" contested and challenged through life experience. In fact, what so called fixed identity does not exist at all. Hall in Rutherford (1990: 226) states that,

Cultural identity is not a fixed essence at all, lying unchanged outside history and culture. It is not some universal and transcendental spirit inside us on which history has made no fundamental mark.... Cultural identities are the points of identification, the unstable points of identification of suture, which are made, within the discourse of history and culture. Not an essence, but positioning

Therefore, identity identification is a never-ending process which continuously change based on the situation. Furthermore, Hall in Rutherford (1990: 225) regards identity as a flexible construction, a process covers not only 'being', but also 'becoming', a principle difference between "who we are" and "what we become". This becoming process is also continuously progressing depending on social and cultural condition of certain place and time. As a result, the values will always change along with the changing of culture and history.

The concept of identity cannot be separated from 'home' because it is determined by 'space' and the individual identity. According to Rainwater (1966: 22), the traditional concept of 'home' is 'secure place' where people feel comfortable. The notion of home as social order is embodied not in a house but based on people's experience and behavior in society. For immigrants and minority groups, the term home is challenged and threatened when they are forced to face the dominant class/culture which becomes the mainstream in society. These people either becomes hybrid or unwanted alien who suffer a sense of alienation. According to Hall (1994:51), “... this idea of otherness as an inner compulsion changes our conception of 'cultural identity'." "That the feeling of otherness, or a sense of non-belonging, or homelessness may trigger an immigrant to redefine his/her identities since it is natural for human being to look for this sense of belongingness. Thus, immigrant's identities are constantly producing and reproducing themselves anew, through transformation and difference

\subsection{Result and Discussion}

\subsubsection{Eilis' Conflicts: Exiled in My Own Land and Foreign Land}

The movie Brooklyn is opened with Eilis' plan to emigrate to United States. Eilis is a young woman who lives in small Irish town of Enniscorthy in the early 1950s with her older sister, Rose, and widowed mother. While Rose is the breadwinner of the family who has decent job in the office, Eilis feels that her small hometown does not offer job opportunity and promising future. It is reinforced by the conversations below.

Eilis : You bought most of the clothes in this case. That's one of the reasons I'm going, cause I

can't buy my own.

Rose: If it was just that, I'd spend every penny I had on you. Gladly. But I can't buy you

a. future. I can't buy you the kind of life you need.

(Crowley, 2015, 00:07:25-00:07:38)

Father Floods : Well, I was amazed that someone as clever as you couldn't find proper work at home. I've been here too long, I forget what it's like in Ireland

(Crowley, 2015, 00:25:09) 
There are two things that become the reason of Eilis' departure to America, those are material possession and better future. Irish people have left their hometowns and emigrated to the America or England to find work and better living. In consequence, the Irish have become the sub class in both England and United States and continually confront racial integration (Inan, 2012: 97).

For Eilis, leaving home and going to place far away from home is not easy as it means she has to leave her widowed mother alone for indefinite period of time. As Ms. Kelly, her former employer said, "mothers are always being left behind in this country. But Rose, that's the end for her now, isn't it? She'll be looking after your mother for the rest of her life" (Crowley, 201500:03: 45-00:03:55). However, the lack of opportunity which becomes the source of Eilis' feeling of alienation leads her to leave her hometown to the uncertainty.

The opposite of Enniscorthy, Brooklyn is portrayed as an epitome of a better world which offer better life and opportunities for immigrant. In addition, it also pictured as metropolitan modern city full of diversities. It is not easy for Eilis to leave the familiar: the simple life with Rose and her mother has become the center of Eilis' identity construction for so many years that she finds homesick immediately after the ship departs.

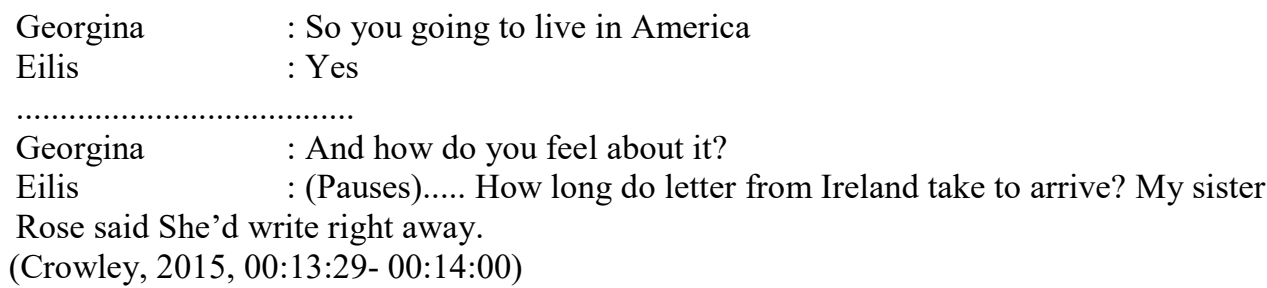

The above conversation happens between Eilis and Georgina, another fellow passenger. It is interesting to note that Eilis avoids the question about how does she feels about living in America which she considers as "difficult" question. By leaving Ireland, Eilis is uprooted from her cultural and ethnic origins, thus she has to struggle in between the past and the unknown future.

This displacement of culture makes Eilis suffer, according to Babha (1994), "acute sense of un-homeliness or in-betweenness". Further, Babha (1994) states that "immigrant or the exiled becomes stranded in that space, a constant of non-belonging, where a person is in constant struggle to assert/locate his/her culture and identity." In Brooklyn Eilis stays in Irish lodging with 5 other girls and she works in a nice big store with nice and helpful supervisor. Amids all mobility and vivacity, she is so liveless and feels like ghost. When Rose's letter arrives, she is so preoccupied with that letter, or the nostalgic feeling that letter brings, and neglects her presence in her 'real' daily life. Her usual gentle and calm manner dissapear as her supervisor asks what makes her so distant with the job, she finally bursts to tears. Eilis confides her depression and homesickness to Father Floods, a priest who arranges Eilis' moving to America.

Father Flood : We need Irish girl in Brooklyn

Eilis $\quad:$ I wish that I could stop feeling that I want to be an Irish girl in Ireland

Father Flood : All I can say is that it will pass. Homesickness is like most sickness.

It'll make you feel wretched and then it'll move on to somebody else.

(Crowley, 2015, 00:25:31-00:25:41) 
From the conversation, it can be concluded that Eilis is torn between two different 'homes'. It is in line with Ascroft, Griffith and Tiffin's (2006:425) explanation below.

Scattering leads to a splitting in the sense of home. A fundamental ambivalence is embedded in the term diapora: a dual ontology in which the diasporic subject is seen to look in two directions: towards a historical cultural identity on one hand, and the society of relocation on the other.

Thus, immigrant as diasporic subjects may feel a kind of loss of home at home. Eilis is an Irish young woman who lives in America which is supposedly to be her 'home', but she is always reminded that she is Irish.

Soon after her live in America becomes bearable with the help of companion and love, Eilis receives the news about Rose's sudden death. Again, Eilis is torn between the two world she lives in, between desire to live freely in the new world and the duty she has to her culture and ancestors. She even tells Tony, her boyfriend that "I'm not sure I have a home anymore" (01:02:20). After her secret and hasty marriage with Tony, Eilis comes back home in Enniscorthy only to realize "how little it meat for her" (01:09:15). Surprisingly, life in Ireland becomes friendlier to her: she gets a job and attention from upper class society and men. It clears America has made her glamorous and desirable, as her best friends, Nancy points out "You look so glamorous" (01:10:15).

Having spent sometimes in multicultural city of Brooklyn has broaden her mindset about diversity and more importantly sense of individualism. Therefore, the small town of Enniscorthy in which she was born now seems very small for her. Perhaps the geographical smallness of the town, together with the smallness of their community and people's attitude, has created another sense of alienation in her. In that small town, the people seem to know the life of one another, news and secret travels fast and becomes public consumption and entertainment. When Miss Kelly, her former employer threatens her with the gossip about her marriage, Eilis firmly exclaims "I'd forgotten what this town is like. What were you planning to do, Miss Kelly? Perhaps you don't even know." Upon returns to home culture, immigrants, like Eilis, may realize that they are no longer considered full members within their own culture due to assimilation they undergo in host country. It is ironic that when Eilis thinks she found the root of her identity, she also realizes that it never exists in the first place.

\subsection{Eilis' Journey to Find Sense of Belonging}

As previously discussed, the protagonist of the movie, Eilis, feels herself out of place not only in her home, Ireland, but also in metropolitan Brooklyn. As an exile, her positions and identity constantly vacillate and she finds herself homeless in both places. To overcome these conflicts, Eilis continuously tries to (re)locate herself and (re)construct her identity. In general, Eilis' journey to find sense of belonging can be divided into three, namely 1) being American, 2) maintain Irishness and 3) attain hybrid identity.

One way of dealing with entering into a new culture is the assimilation strategy. Singaravelua and Pope in Etoroma (2006) mention that the assimilation strategy is done by trying to disengage partly or completely from their origin in hopes of being completely absorbed and accepted into the dominant host culture. Further, Etoroma (2006) also adds that "an immigrant group is at home when it is "structurally assimilated into society." It is important for immigrant, then to assimilate in host culture to gain a sense of belongingness. It is done by Eilis in her first departure to America which can be seen from monologue below.

Eilis : When you get to immigration, keep your eyes wide open. Look as if you know where you are going. You have to think like an American.

(Crowley, 2015, 01:43:15) 
'Thinking like American" seems to be important point here. Acting and thinking like Americans become strategy to survive and be accepted in host culture. By doing so, indirectly she opens the possibility to assimilate with larger American culture. It is important for immigrant to create bond and a sense of home in new culture since "migration is a one-way trip and there is no "home" to go back to" (Hall in Rutherford, 1990:115).

It is indeed that to assimilate with the host culture is the first effort made by Eilis in order to be able to survive in America. However, to assimilate in new culture is never easy since naturally, people will be attracted and form community with people based upon similarities than differences. Nedumchira in Simonis (2012: 65) argues that "sharing a sense of sameness with the large group provide a sense of belonging and protection". In other words, as a type of protection mechanism, due to the being treated as the 'other', immigrants form group allowing members to stick together and create their own small community within the larger, host community.

During her stays in America, she lives in small Irish world: living in Irish lodging with five other Irish girls, and also actively participating in Irish community where she can enliven Irish tradition. Mrs. Kehoe, the landlady also helps Eilis in maintaining the Irishness by establishing catholic correctness. In one occasion, Eilis agrees to participate in Christmas gathering for Irish people arranged by Father Flood.

Mrs. Kehoe : Eilis, Father Flood told me about your Christmas plans

Sheila : Oh, you're not serving lunch to the old fellas who've nowhere to go, are you? He asks us every year. We always say no.

Mrs Kehoe $\quad$ : It's a marvelous thing you're doing, Eilis. A Christian thing. I wish

there were

more like you.

(Crowley, 2015, 00:26:52-00:27:10)

In this Christmas gathering she and many other Irish people celebrate their tradition and nostalgic feeling about Ireland. it can be said that being a member of this community may help immigrants deal with feelings of displacement, homelessness and feeling like a stranger in the host country.

In the end of the movie, Eilis realizes that her experience in America somehow changes her perspective and identity. She cannot separate her Irishness and her Americanness since those two cultures have become parts of her. It is clearly seen from her decision to voluntary exile to America again to escape the narrowness of small town Enniscorthy. By doing so, Eilis wants to locate herself in a larger world - a citizen of the world. This decision also portrayed in her remark in the end of the movie below.

Eilis : You'll feel homesick that you'll want to die and there's nothing you can do about it apart from endure it. But you will, and it won't kill you. And one day the sun will come out. You might not even notice straightaway, it'll be that faint. And then you'll catch yourself thinking about something or someone who has no connection with the past, someone who'll only yours and you'll realize that this is where your life is.

(Crowley, 2015, 01:43:24-01:44:18)

It depicts Eilis' willingness to embrace hybridity, she finally understands that one's identities are never fixed but always in motion, and so is hybridity. Hybridized identities have a different outlook on the world, "learning to keep in mind the 'both/and' as opposed to the either/or of the experience is helping to appreciate these dual cultures that are each alive within them" (Nedumchira in Simonis, 2012). Thus, hybridity can be seen as a bridge because hybridized people have unique connection between cultures which allow them to shift perceptions of cultural values, traditions, rules, and norms. 


\section{CONCLUSIONS}

Eilis' quest for home started at the moment when she accepts to leave Enniscorthy quietly and understand that to emigrate is to become a foreigner in two places at once. Being constantly exiled in both home and foreign countries create the feeling of displacement, homelessness and acute homesickness in her. Therefore, she continuously reconstructs and redefines her identity by assimilating to host culture and celebrating her Irishness. Finally, she embraces both cultures as part of her which put herself as hybrid person.

\section{REFERENCES}

[1] Ascroft, B., Griffiths, G., Tiffin, H. 2006. The Post-Colonial Studies Reader. London: Routledge.

[2] Babha, Homi K. 1994. The Location of Culture. London: Routledge.

[3] Crowley (dir.). 2015. Brooklyn. BBC Films, Telefilm Canada, HanWay Films, Wildgaze Films

[4] Etoroma, E.E. 2006. Finding Home. International Journal of Diversity in Organizations, Communities and Nations, 6(3), pp.103-110.

[5] Hall, Stuart (Ed.). 1997. Representation: Cultural Representations and Signifying Practices. London: Sage Publications Ltd.

[6] Inan, Dilek. 2012. Colm Toibin's Brooklyn: Caught between Home and Exile. Philologist: Journal of Language, Literary and Cultural Studies, V-2012, pp. 96-104

[7] MacIntyre, A. 1981. After Virtue. London: Duckworth

[8] Rainwater, L. 1966. Crucible of Identity: The Negro Lower-Class Family.

[9] Rutherford, Jonathan (ed.). 1990. Identity: Community, Culture, Difference. London: Lawrence and Wishart.

[10] Simonis, J. 2012. Home and Identity: Displacement, Belonging and Hybridity in International Students on US Campuses. Southern Illinois University Carbondale OpenSIUC. Spring 4-2012. http://opensiuc.lib.siu.edu/gs_rp/243

[11] Woodward, Kathryn. 1997. Identity and Difference. London: Sage Publication. 